\title{
Marine and terrestrial factors affecting Adélie penguin Pygoscelis adeliae chick growth and recruitment off the western Antarctic Peninsula
}

\author{
Erik W. Chapman ${ }^{1,4, *}$, Eileen E. Hofmann ${ }^{1}$, Donna L. Patterson ${ }^{2}$, Christine A. Ribic ${ }^{3}$ \\ William R. Fraser ${ }^{2}$ \\ ${ }^{1}$ Center for Coastal Physical Oceanography, Old Dominion University, 4111 Monarch Way, Norfolk, Virginia 23529, USA \\ ${ }^{2}$ Polar Oceans Research Group, PO Box 368, Sheridan, Montana 59749, USA \\ ${ }^{3}$ US Geological Survey Wisconsin Cooperative Wildlife Research Unit, Dept. Forest and Wildlife Ecology, \\ University of Wisconsin, Madison, Wisconsin 53706, USA \\ ${ }^{4}$ Present address: New Hampshire Sea Grant, University of New Hampshire Cooperative Extension, \\ 131 Main Street, Durham, New Hampshire 03824, USA
}

\begin{abstract}
An individual-based bioenergetics model that simulates the growth of an Adélie penguin Pygoscelis adeliae chick from hatching to fledging was used to assess marine and terrestrial factors that affect chick growth and fledging mass off the western Antarctic Peninsula. Simulations considered the effects on Adélie penguin fledging mass of (1) modification of chick diet through the addition of Antarctic silverfish Pleuragramma antarcticum to an all-Antarctic krill Euphausia superba diet, (2) reduction of provisioning rate which may occur as a result of an environmental stress such as reduced prey availability, and (3) increased thermoregulatory costs due to wetting of chicks which may result from increased precipitation or snow-melt in colonies. Addition of $17 \%$ Antarctic silverfish of Age-Class 3 yr (AC3) to a penguin chick diet composed of Antarctic krill increased chick fledging mass by $5 \%$. Environmental stress that results in $>4 \%$ reduction in provisioning rate or wetting of just $10 \%$ of the chick's surface area decreased fledging mass enough to reduce the chick's probability of successful recruitment. The negative effects of reduced provisioning and wetting on chick growth can be compensated for by inclusion of Antarctic silverfish of AC3 and older in the chick diet. Results provide insight into climate-driven processes that influence chick growth and highlight a need for field research designed to investigate factors that determine the availability of AC3 and older Antarctic silverfish to foraging Adélie penguins and the influence of snowfall on chick wetting, thermoregulation and adult provisioning rate.
\end{abstract}

KEY WORDS: Adélie penguin · Climate change $\cdot$ Chick growth $\cdot$ Antarctic Peninsula Resale or republication not permitted without written consent of the publisher

\section{INTRODUCTION}

For many seabirds, including Adélie penguins off the western Antarctic Peninsula (wAP), survival and recruitment of chicks is positively correlated with fledging mass, the mass of chicks immediately prior to permanently leaving the nest site (Hunt et al. 1986). Presumably, heavier chicks are more likely to recruit because they have larger energy reserves with which to survive the energetic stresses associated with learning to find and capture prey and surviving the Antarctic winter. Fledging mass has also been positively correlated with trends in Adélie penguin colony size off the wAP (Hinke et al. 2007), suggesting that alteration of chick growth processes may be closely linked to population trajectory for this species. Thus, improving our understanding of Adélie penguin chick growth processes may provide insight into mechanisms that 
underlie recruitment and, ultimately, population dynamics for this species. The present study uses an individual-based bioenergetics modeling framework to explore the link between environmental conditions and chick growth, fledging mass, and recruitment for Adélie penguins off the wAP, where penguin populations have been changing presumably in response to changes in environmental conditions, including climate warming (Ducklow et al. 2007).

The most important factors that affect seabird chick growth and fledging mass are prey quality (Davoren \& Montevecchi 2003), prey abundance and distribution (which influence prey availability and the rate at which parents can provide food to chicks) (Croxall et al. 1999), and metabolic losses experienced at the nest (Taylor 1985). Additional factors that may influence provisioning rate and chick growth (by influencing prey distribution and abundance) include top-down processes (Ainley et al. 2007, 2009), including intraspecific competition indexed by colony size (Ainley et al. 1998, Hipfner et al. 2007) and inter-specific competition with whales (Ainley et al. 2006). Although longterm trends in whale abundance are not well documented, there is some evidence that several whale species, most notably humpback whales Megaptera novaeangliae (Branch 2006), are increasing off the wAP, causing greater competition between penguins and whales for food in this region.

Climate variability can influence chick growth processes by altering physical-biological connections in the ecosystem that determine the species, age-class, quality, and availability of prey and by altering conditions at nests. Over the past $50 \mathrm{yr}$, the wAP region has experienced dramatic climate warming which has been associated with alteration of the region's physical environment (Turner et al. 2005a, Stammerjohn et al. 2008) and, consequently, the wAP marine ecosystem. One result of these environmental changes appears to be a shift in abundance and distribution of mid-trophic level prey species that mediate the transfer of energy from primary production to Adélie penguins (Clarke et al. 2007, Ducklow et al. 2007). For example, Antarctic krill Euphausia superba, the primary prey item for wAP Adélie penguins off the mid- to northern wAP (Fraser \& Trivelpiece 1996, Hinke et al. 2007), has experienced a reduction in abundance while populations of salps (dominated by Salpa thompsoni), a group of species that is not known to be eaten by Adélie penguins, has increased (Atkinson et al. 2004). In addition, Antarctic silverfish Pleuragramma antarcticum, a species that was present historically in wAP Adélie penguin diets (Emslie \& Patterson 2007), is not currently a diet component at some locations off the wAP, including colonies near Anvers Island (W. R. Fraser unpubl. data). This suggests a change in Antarctic silverfish distribution and, therefore, their availability to foraging Adélie penguins (and hence to their chicks) in this region (Emslie \& Patterson 2007).

Changes occurring in Adélie penguin colonies off the wAP may also be influencing chick growth. The wAP has experienced increased precipitation as a result of climate warming (Turner et al. 2005b), which potentially enhances the role of terrestrial effects on Adélie penguin chick growth through increased exposure to water from rainfall or snow-melt (Patterson et al. 2003). While increased temperatures can slightly reduce the thermoregulatory costs of chicks, increased melt-water in the colonies causes wetting of chicks which can amplify thermoregulatory costs (i.e. the wetting effect) (Lustick \& Adams 1977, Wilson et al. 2004) and reduce growth.

Models are an accepted way of organizing hypotheses about processes in complex systems and exploring consequences of potential changes. Chapman et al. (2009) used a model to understand how Adélie penguin chick growth and recruitment may be affected by changes in diet quality due to variability in Antarctic krill spawning schedule, krill sex ratios and/or maturity stage composition. This model was developed in the tradition of mechanistically rich, process-oriented, individual-based models (DeAngelis \& Mooij 2005, Grimm \& Railsback 2005) that seek to capture the most important processes within a system while parameterizing components using data wherever possible. This modeling approach provides insight into the phenomenon of interest when many parameters are not well understood and/or when data collection is limited or logistically problematic (such as in the Antarctic). In these circumstances, models of this type are useful ways of exploring mechanistic interactions and potential outcomes within specific scenarios and are effective in developing new hypotheses and guiding future modeling and field-based research. For example, simulations presented in Chapman et al. (2009) were used to develop hypotheses that have driven field research within at least 1 Antarctic research program (the US Palmer Long Term Ecological Research Program).

Here, we use the modeling approach employed by Chapman et al. (2009) to understand how Adélie penguin chick growth, fledging mass, and recruitment off the wAP may be influenced by (1) alterations in diet composition (specifically through the addition of fish to an Antarctic krill diet), (2) altered provisioning rate resulting from a change in prey availability, and (3) increased thermoregulatory costs due to chick wetting caused by snow-melt water in colonies. Overall, the simulations are designed to provide insight into factors linked to climate change off the wAP that influence Adélie penguin chick growth, while identifying areas for future field studies. 


\section{METHODS}

Approach. To assess the effect of diet complexity on Adélie penguin Pygoscelis adeliae chick growth, a model that has been developed to represent current breeding conditions near Anvers Island off the wAP (Chapman et al. 2009) was modified and run through a set of simulations. The provisioning schedule and Antarctic krill Euphausia superba energy density obtained from the Adélie penguin chick growth simulations (Chapman et al. 2009) provided the basis for reference simulations in the present study. We evaluated the simulation results by comparing simulated fledge mass with the re-sighted fledge mass (RFM, $3.15 \pm$ $0.352 \mathrm{~kg}, \mathrm{n}=152$ ) and the not re-sighted fledge mass (NRFM, $3.03 \pm 0.258 \mathrm{~kg}, \mathrm{n}=2030$ ). The difference between these 2 means, $0.117 \mathrm{~kg}$, is small, but statistically significant ( $t$-test, $\mathrm{p}<0.001$ ). RFM is the mean mass of fledging chicks that recruited into the population, and the NRFM is the mean mass of fledging chicks that did not recruit, based on a chick-banding study near Anvers Island (Chapman et al. 2009). The RFM and NRFM provide criteria for determining conditions that are more or less likely to produce a chick that will eventually recruit to the breeding population (i.e. a viable chick). For example, conditions that reduce the chick fledging mass from the RFM to the NRFM are considered sufficient to significantly reduce the probability of recruitment for a chick. We assume that if this represents a change in mean fledging mass for a given population, the modeled change would have important implications for the fate of that population.

Chick growth model. We modified the Adélie penguin chick growth model developed by Salihoglu et al. (2001) and revised by Chapman et al. (2009); a summary of the model structure can be found in Appendix 1. The model was designed to represent current chick growth conditions off Anvers Island, wAP. The modeling described in the present study involves parameters (Table 1) required to represent processes that affect chick growth during a typical nesting period at Anvers Island (19 December to 10 February). The governing equation for the model assumes that chick growth, expressed as the change in mass over time, can be calculated as the difference between assimilated energy and that lost to metabolic costs scaled by the chick wet mass energy density. The energetic costs experienced by the chick are determined by the mean metabolic rate and the cost associated with tissue maturation (the energy density of chick tissue increases with chick age, in part because new material is produced that replaces water in the chick tissue). Mean metabolic rate, water content, chick dry mass energy density, and assimilation efficiency vary with chick age

Table 1. Symbols, values, and definitions for parameters used in the present study

\begin{tabular}{|c|c|c|c|}
\hline Parameter & Value (range) & Unit & Definition \\
\hline $\operatorname{Lip}_{\max }$ & 0.43 & & Maximum proportion lipid for Antarctic silverfish Pleuragramma antarcticum \\
\hline $\operatorname{Lip}_{\min }$ & 0.12 & & Minimum proportion lipid for Antarctic silverfish \\
\hline$k_{\text {lip50 }}$ & 50 & $\mathrm{~mm}$ & Fish length at which Antarctic silverfish lipid content is $50 \%$ of maximum value \\
\hline$k_{\text {lip }}$ & 0.1 & $\mathrm{~mm}^{-1}$ & $\begin{array}{l}\text { Factor controlling the rate of increase in Antarctic silverfish lipid content with } \\
\text { fish length }\end{array}$ \\
\hline$L_{\mathrm{s} \infty}$ & 256.9 & $\mathrm{~mm}$ & Antarctic silverfish maximum length \\
\hline$t_{\mathrm{s} 0}$ & -1.49 & yr & $\begin{array}{l}\text { Moves Antarctic silverfish growth curve along time axis to avoid length } \leq 0 \text { at } \\
\text { hatching }\end{array}$ \\
\hline$k_{\mathrm{s}}$ & 0.06 & $\mathrm{yr}^{-1}$ & Factor controlling the Antarctic silverfish rate of growth \\
\hline$\sigma$ & $5.67 \times 10^{-8}$ & 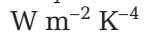 & Stefan-Boltzmann constant \\
\hline$T_{\mathrm{b}}$ & 305 & $\mathrm{~K}$ & Temperature at chick's skin \\
\hline$\varepsilon$ & 0.8 & Unitless & Emissivity of keratin \\
\hline$n_{\mathrm{mm}}$ & 1.0 layer & $\mathrm{mm}^{-1}$ & Density of down insulating layers \\
\hline$C_{\mathrm{H}}$ & $1.1 \times 10^{-2}$ & Unitless & Stanton number \\
\hline$C_{\mathrm{p}}$ & 1.032 & $\mathrm{~J} \mathrm{~g}^{-1} \mathrm{~K}^{-1}$ & Specific heat of water \\
\hline$d x$ & $8-27$ & $\mathrm{~mm}$ & Depth of chick down \\
\hline$k_{\text {water }}$ & $6.13 \times 10^{-1}$ & $\mathrm{~W} \mathrm{~m} \mathrm{~m}^{-2} \mathrm{~K}^{-1}$ & Conductivity of water \\
\hline$k_{\text {air }}$ & $2.6 \times 10^{-2}$ & $\mathrm{~W} \mathrm{~m} \mathrm{~m}^{-2} \mathrm{~K}^{-1}$ & Conductivity of air \\
\hline$D$ & $1.5 \times 10^{-3}$ & Unitless & Diffusion coefficient (Dalton's number) \\
\hline$H_{\text {evap }}$ & $2.26 \times 10^{3}$ & $\left(\mathrm{~W} \mathrm{~g}^{-1}\right)$ & Latent heat of evaporation \\
\hline$u_{\mathrm{m}}$ & $0.4(0.1-1.0)$ & Unitless & $\begin{array}{l}\text { Modification of wind speed due to microclimate selection and physical barrier } \\
\text { of plumage }\end{array}$ \\
\hline wet $_{\text {mod }}$ & $0.5(0.05-0.90)$ & Unitless & Modification of down depth resulting from exposure to water \\
\hline$p_{\text {water }}$ & $5.0(0.1-20.0)$ & $\%$ & Percent of down complex that is water \\
\hline$P_{\text {wet }}$ & $5(1-25)$ & $\%$ & Percent of chick that is wet \\
\hline
\end{tabular}



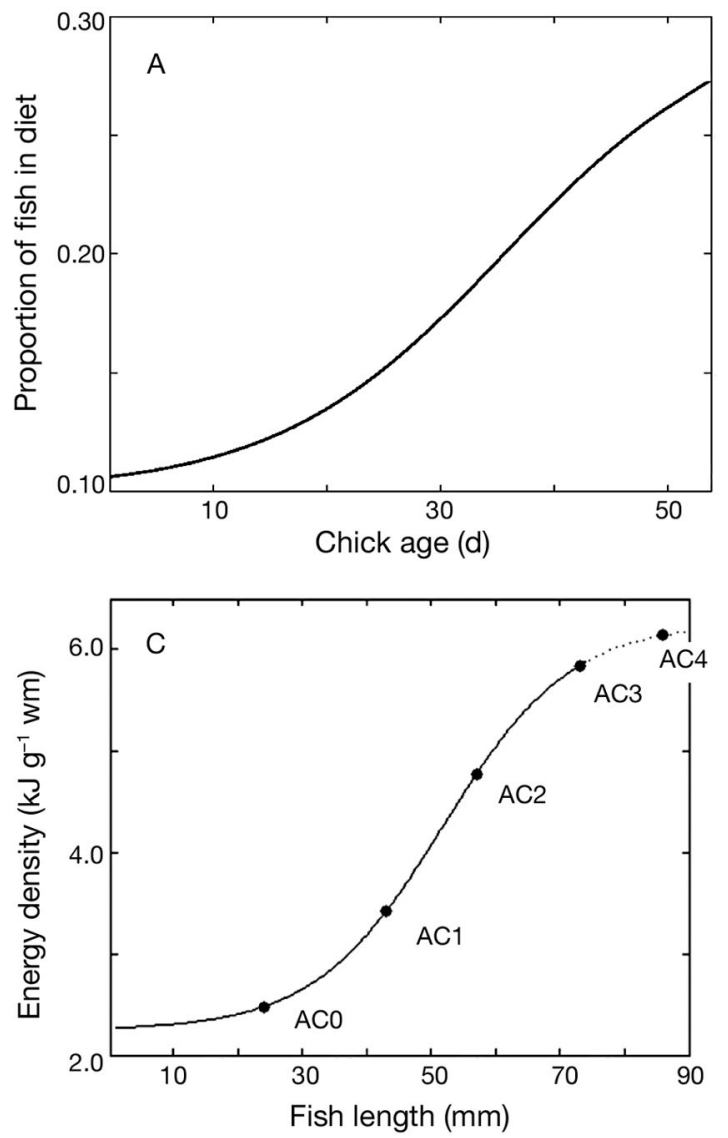

and size. The daily amount of food provisioned to a chick (provisioning rate) was assumed to slowly increase initially, then increase rapidly as the chick's energy demands increase, and to reach a plateau prior to fledging. Provisioning rate was constrained by the adults' ability to provide food and the chick's capacity to ingest food and was sufficient to produce chicks that grew according to measured Adélie penguin chick growth rates. Adult Adélie penguins generally stop provisioning their chicks during a starvation period between 3 and $7 \mathrm{~d}$ prior to fledging, so adults no longer provision food to chicks in the model after Day 50 of the nestling period. During this period, chicks lose mass until they leave the colony at their fledging mass to begin foraging for themselves.

Fish simulations. Prey wet mass energy density for the Antarctic krill diet is estimated as described in Chapman et al. (2009) and is a function of lipid content which varies with krill sex and/or maturity stage distribution and season (Clarke 1980, Virtue et al. 1996, Hagen et al. 2001). We modified the model to calculate prey wet mass for diets when fish are included.

Fish can be an important component of the Adélie penguin diet. The proportion of fish in the diet can vary

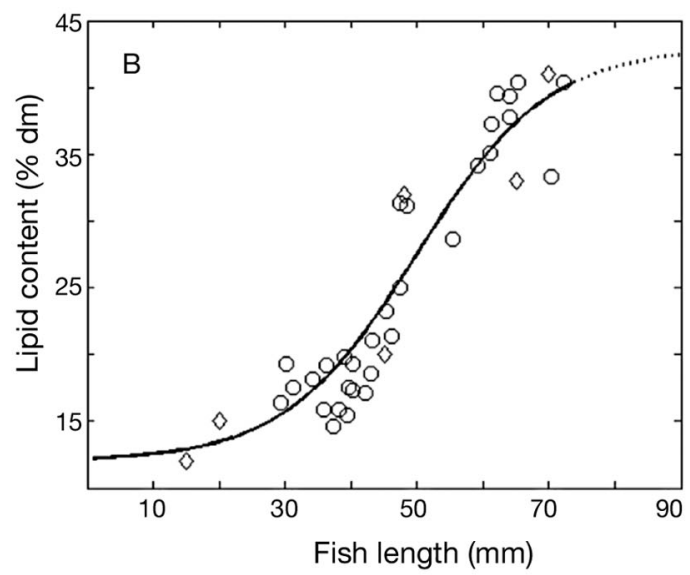

Fig. 1. (A) Change in proportion of fish in the Adélie penguin Pygoscelis adeliae chick diet over the chick growth period, based on Ainley et al. (2003). (B) Lipid content (\% dry mass) measured for Antarctic silverfish Pleuragramma antarcticum by (O) Hubold \& Hagen (1997) and ( $\diamond)$ Hagen et al. (2000). The estimated relationship between fish length and energy density used to calculate modeled energy density for each age-class of Antarctic silverfish is also shown. (C) The relationship (solid curve) between length and energy density (wm = wet mass) for Antarctic silverfish used to obtain energy density for age-classes (AC) 0 to 4 yr. Energy densities for the mean length of AC0 through AC4 fish are indicated by filled circles. In Panels B and C, the segment of the modeled lipid content and energy density relationship to fish length that extends beyond the available data is also indicated (dotted curve)

over the nestling period, and our model allows the proportion of fish in the chick diet to increase as the chick ages over the chick growth period, as was seen by Ainley et al. (2003) (Fig. 1A). The proportion of fish in the diet of breeding Adélie penguins can be higher than was used in the present study (mean of 0.17) (Ainley et al. 2003). However, the values used here are within the lower range of observations and provide a test of the effects on Adélie penguin chick growth of a small, but realistic increase of fish in the chick diet.

Ropert-Coudert et al. (2002) found no difference in Adélie penguins foraging when feeding on fish or krill, though Ainley et al. (2006) found somewhat longer foraging trips when foraging on fish. Due to this uncertainty, this model does not account for changes in chick feeding rate related to differences in adult foraging behavior when feeding on either krill or fish.

For the fish simulations, a reference scenario where an all-krill diet produced a $3.09 \mathrm{~kg}$ fledgling (mean of the RFM and NRFM) was used to allow the model results to be sensitive to either positive or negative effects of adding fish for chick growth.

Antarctic silverfish energy density. Antarctic silverfish energy density as a function of fish length (Fig. 1B) 
was developed from measurements (Hubold \& Hagen 1997, Wöhrmann et al. 1997, Hagen et al. 2000) that relate lipid content and fish length $(L)$ as:

$$
\operatorname{Lip}(L)=\left[\left(\operatorname{Lip}_{\max }-\operatorname{Lip}_{\min }\right) \cdot \frac{1}{1+\mathrm{e}^{-k_{\text {lip }}\left(L-k_{\text {lip } 50)}\right.}}\right]+\operatorname{Lip}_{\text {min }}
$$

where Lip $_{\max }$ is the maximum lipid content (proportion dry mass $=0.43), \operatorname{Lip}_{\min }$ is the minimum lipid content (proportion dry mass $=0.12), k_{\text {lip }}\left(0.1 \mathrm{~mm}^{-1}\right)$ controls the rate of increase in lipid content with increasing $L(\mathrm{~mm})$, and $k_{\text {lip } 50}(50 \mathrm{~mm})$ is the $L$ at which the lipid content is $50 \%$ of its maximum value. No data are available for lipid content of Antarctic silverfish longer than around $74 \mathrm{~mm}$. However, lipid content as a function of size was estimated just beyond the available data.

The dry mass proportion of protein (0.85), carbohydrate (0.01), and skeletal ash (0.14) (biochemical composition) in the non-lipid portion of Antarctic silverfish was assumed to be similar to that of Electrona antarctica (Donnelly et al. 1990). The percent water composition of Antarctic silverfish decreases from 90 to $78 \%$ as $L$ increases to its maximum value (Torres unpubl. data). The lipid content, the non-lipid biochemical composition, and the percent water composition were then used to calculate wet mass biochemical composition as a function of Antarctic silverfish length. Finally, the energy density of each biochemical component (lipid $=0.0395 \mathrm{~kJ} \mathrm{~g}^{-1}$, protein $=0.0236 \mathrm{~kJ} \mathrm{~g}^{-1}$, carbohydrate $=0.0172 \mathrm{~kJ} \mathrm{~g}^{-1}$, ash $=0.0 \mathrm{~kJ} \mathrm{~g}^{-1}$ ) was used to calculate wet mass energy density as a function of Antarctic silverfish length (Fig. 1C).

Antarctic silverfish $L$ was then related to specific age-classes (AC) using growth parameters determined for von Bertalanffy growth (Eq. 2) from studies done in the Weddell Sea (Hubold \& Tomo 1989) and the wAP (Radtke et al. 1993). The von Bertalanffy growth equation is:

$$
L(t)=L_{\mathrm{s} \infty} \cdot\left[1-\mathrm{e}^{\left(k_{\mathrm{s}}\left(t_{\mathrm{y}}-t_{\mathrm{s} 0}\right)\right)}\right]
$$

where $L_{\mathrm{s} \infty}$ is the maximum length of the fish (256.9 $\mathrm{mm}), t_{\mathrm{y}}$ is fish age in years, $t_{\mathrm{s} 0}(-1.49 \mathrm{yr})$ moves the growth curve along the age axis and allows for nonzero length at hatching ( $L$ at time $=0 \mathrm{yr})$, and $k_{\mathrm{s}}(0.06$ $\mathrm{yr}^{-1}$ ) controls the rate of length increase (Hubold \& Tomo 1989, Radtke et al. 1993). We do not estimate the lipid content for fish beyond the range of available data for this relationship (Fig. 1B), so only age-classes up to AC4 were included as part of the chick diet. These lengths were then used to obtain energy density values for each age-class based on Eq. (1) and the estimated fish biochemical composition (Fig. 1C).

Provisioning schedule simulations. We tested for the influence on fledging mass of increasing the starvation period from 1 to $3 \mathrm{~d}$ and decreasing the daily provision- ing rate by up to $10 \%$. These simulations were conducted for an all-krill diet and for a diet that included both Antarctic krill and AC3 Antarctic silverfish.

For the variable provisioning rate, we expected simulations to produce smaller chicks, and a reference scenario that produced a chick with a fledging mass of $3.15 \mathrm{~kg}$, the RFM, was used. Thus, simulation conditions that reduced fledging mass from the RFM to the NRFM were interpreted as sufficient to negatively affect a chick's probability of recruitment.

Chick wetting simulations. Parameterization of the wetting effect: While the fish simulations and provisioning simulations involved mainly processes that have been included in several published chick growth models (Salihoglu et al. 2001, Chapman et al. 2009), this is the first attempt, that we are aware of, to model the wetting effect on chick growth. Several new components were developed for these simulations that are novel, considerably more complex, and involve many processes and parameters that are not well studied. As a result, sensitivity simulations were designed for this portion of the study, and results should be interpreted accordingly.

The presence of water in a chick's down influences all modes of heat transfer through the skin/feather complex. Heat transfer, or the conductance of heat through the insulation provided by skin and feathers, was calculated as (Chappell \& Souza 1988)

$$
C=\frac{M_{\text {heat }}}{T_{\mathrm{b}}-T_{\mathrm{e}}}
$$

where $C$ is the dry thermal conductance $\left(\mathrm{W} \mathrm{kg}^{-1} \mathrm{~K}^{-1}\right)$, $M_{\text {heat }}\left(\mathrm{W} \mathrm{kg}^{-1}\right)$ is the net metabolic heat production or the total metabolic rate minus evaporative heat loss from respiration, $T_{\mathrm{b}}(\mathrm{K})$ is the body temperature of the chick immediately beneath the skin, and $T_{\mathrm{e}}(\mathrm{K})$ is the chick's operative temperature (the effective temperature experienced by a particular object, in this case a penguin chick). Although there may be some additional heat loss due to transcutaneous evaporation, the contribution to total heat flux was assumed to be negligible for birds and was not included in the model. For simulations, body temperature is assumed to be constant. Chappell et al. (1990) provide a relationship to obtain the operative temperature of the form:

$$
T_{\mathrm{e}}=0.69\left(T_{\mathrm{a}}-273\right)+0.28\left(Q_{\mathrm{sol}}\right)-0.0056\left(Q_{\mathrm{sol}} \cdot u^{0.5}\right)+274.47
$$

where $T_{\mathrm{a}}$ is air temperature $(\mathrm{K}), Q_{\text {sol }}$ is incident solar radiation $\left(\mathrm{W} \mathrm{m}^{-2}\right)$, and $u$ is wind speed $\left(\mathrm{m} \mathrm{s}^{-1}\right)$ at chick height. Although the presence of water in and around the chick may influence operative temperature, a simple adjustment is not available to account for this influence and the same operative temperature is used for wet and dry chicks. 
Dry thermal conductance is the sum of all modes of heat loss through the skin/feather complex of the chick. Air and keratin, the protein in feather tissue, are the insulating materials that are influenced by the presence of water in a chick's down. The introduction of water to a chick's feathers causes mechanical disruption of the insulating structure of the feathers (removal of air space) and adds water to the down, increasing the rate of thermal conductance through the skin/feather complex and adding evaporative heat loss to the total heat flux from the chick. Evaporative heat loss from respiration is assumed to not change significantly when a chick is wet. Therefore, any proportional change in the loss of heat from the bird due to wetting results in an increase in total metabolic rate of the same proportion. While this assumption does not account for the chick's ability to account for some of the additional heat loss through alternative mechanisms (e.g. cutaneous vasoconstriction, postural adjustments), it captures the main processes responsible for increased metabolism caused by the wetting of chick down. With this assumption, the effect of wet chick down on metabolic costs is proportional to the increase in total heat loss through the skin/feather complex caused by the wetting. Therefore, to estimate the cost of wetting, the total heat loss for a dry and a wet chick is calculated. Unlike the fish and provisioning schedule simulations, the calculations for the wetting effect simulations require detailed information on the weather conditions experienced by the chick, and the following calculations were made only for the wetting effect simulations. The total heat loss for a chick is the sum of radiative, convective, conductive heat transfer (Cena \& Monteith 1975a,b,c, Dawson et al. 1999), and the latent heat of evaporation (Cena \& Monteith 1975c) through a chick's skin/feather complex.

Radiative heat loss: It is assumed that chick down has similar structural properties to the downy adult after-feather which provides most of the insulating properties for an adult penguin (Dawson et al. 1999). Therefore, we used the approach of Dawson et al. (1999) for calculating net radiant heat flux through adult feathers. Dawson et al. (1999) calculated that the downy portion of the penguin feather created a cell of insulating air for each millimeter of its length as barbules from the feather latched onto those of neighboring feathers. Each layer was assumed to absorb radiated heat from the surface closer to the bird and radiate that heat in all directions, thereby reducing radiative heat loss by half at each layer. With these

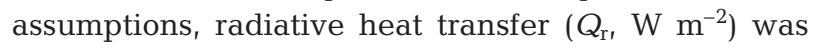
calculated as:

$$
Q_{\mathrm{r}}=\frac{\sigma\left(T_{\mathrm{s}}^{4}-T_{\mathrm{e}}^{4}\right)}{(n+1)\left(\frac{2}{\varepsilon-1}\right)}
$$

where $\sigma$ is the Stefan-Boltzmann constant $\left(\mathrm{W} \mathrm{m}^{-2} \mathrm{~K}^{-4}\right)$, $T_{\mathrm{s}}(\mathrm{K})$ and $T_{\mathrm{e}}(\mathrm{K})$ are the skin and operative temperatures, respectively, $n$ is the number of insulating layers of air, and $\varepsilon$ is the emissivity of keratin. The value for $T_{\mathrm{e}}$ varies daily and is calculated using Eq. (1). The value for $n$ is a function of the depth of the chick down and the number of insulating layers per millimeter of down $\left(n_{\mathrm{mm}}\right)$ which is assumed to be 1.0 (Dawson et al. 1999).

Convective heat loss: Convective heat loss can occur as a result of free (transferred due to buoyancy of heated air) and forced (transferred by wind) convection. Dawson et al. (1999) showed that free and forced convection are not significant through dry adult penguin feathers. Because adult feathers (provided by the downy after-feather) and chick down have similar insulating properties, we assume that free and forced convection are not likely important factors in heat loss for dry Adélie penguin chicks. This is supported by other studies (Taylor 1986, Chappell et al. 1989) that found a minimal influence of wind on the metabolic rates of adults and chicks outside of extremely cold and windy conditions.

While there have been some studies suggesting a thermoregulatory cost for wetting (Lustick \& Adams 1977, McCafferty et al. 1997, Wilson et al. 2004), to date, there have been no observational or theoretical studies of the influence of wind and the consequent forced convective heat loss on wet chicks. Mechanical disruption of the chick's down by water is likely to increase convective heat loss. Forced convective heat loss was calculated using a relationship (Gill 1982) that relates sensible heat loss $\left(Q_{\mathrm{s}}, \mathrm{W} \mathrm{m}^{-2}\right)$ to wind speed $(u$, $\mathrm{m} \mathrm{s}^{-1}$ ) as:

$$
Q_{\mathrm{s}}=C_{\mathrm{H}} \cdot \rho_{\mathrm{a}} \cdot C_{\mathrm{p}} \cdot u\left(T_{\mathrm{s}}-T_{\mathrm{e}}\right)
$$

where $C_{\mathrm{H}}$ is the dimensionless Stanton number, $\rho_{\mathrm{a}}$ is the density of air $\left(\mathrm{g} \mathrm{m}^{-3}\right)$, and $c_{\mathrm{p}}$ is the specific heat of water $\left(\mathrm{J} \mathrm{g}^{-1} \mathrm{~K}^{-1}\right)$. The wind speed was modified to reflect the chick's ability to select an optimal habitat to minimize the effect of wind as:

$$
u=u_{\text {measured }} \cdot u_{\mathrm{m}}
$$

where $u_{\text {measured }}$ is wind speed at chick height and $u_{\mathrm{m}}$ is a factor that reduces the wind speed experienced by the chick due to micro-habitat selection.

Conductive heat loss: When a chick is sufficiently wet, the structural insulating properties of the feathers are significantly reduced and the conductance of the down is influenced by the relatively high thermal conductivity of water. Conductive heat loss under wet conditions was estimated from the relationship drawn from Incropera \& DeWitt (1985):

$$
Q_{\mathrm{x}}=\frac{k_{\text {down }}\left(T_{\mathrm{s}}-T_{\mathrm{e}}\right)}{d \mathrm{x}}
$$


where $Q_{\mathrm{x}}$ is the rate of heat flow through the penguin's feathers $\left(\mathrm{W} \mathrm{m}^{-2}\right), k_{\text {down }}$ is the thermal conductivity of down $\left(\mathrm{W} \mathrm{m}^{-1} \mathrm{~K}^{-1}\right)$, and $d x$ is the thickness of the insulating down layer $(\mathrm{m})$.

The down depth $(d x)$ is modified by the presence of water as:

$$
d x=d x_{\mathrm{dry}} \cdot \text { wet }_{\mathrm{mod}}
$$

where $d x_{\text {dry }}$ is the dry down depth, and wet $t_{\text {mod }}$ is the modification of dry depth by the presence of water (a dry chick would have a wet wod $=1.0$ ). Chick down depth increases with age (Taylor 1986). In the present study, down depth increases from 8 to $27 \mathrm{~mm}$ for chicks between the ages of 10 and $40 \mathrm{~d}$ (Fig. 2A).

Down thermal conductivity $\left(k_{\text {down }}\right)$ is the sum of the conductivity of water $\left(k_{\text {water, }}, \mathrm{W} \mathrm{m}^{-2} \mathrm{~K}^{-1}\right)$ and air $\left(k_{\text {air }}, \mathrm{W}\right.$ $\mathrm{m}^{-2} \mathrm{~K}^{-1}$ ) and is calculated as:

$$
k_{\text {down }}=\left(k_{\text {water }} \cdot p_{\text {water }}\right)+k_{\text {air }} \cdot\left(1-p_{\text {water }}\right)
$$

where $p_{\text {water }}$ (unitless) is the percentage of the down that is saturated with water.

Evaporative heat loss: The extent to which a chick continues to become wet through contact with water (or additional precipitation) determines the potential for evaporative heat loss. Evaporative heat loss as a function of wind speed (Gill 1982) is:

$$
Q_{\mathrm{e}}=H_{\text {evap }} \cdot \rho_{\mathrm{a}} \cdot D \cdot u \frac{q_{\mathrm{s}}}{q_{\mathrm{a}}}
$$
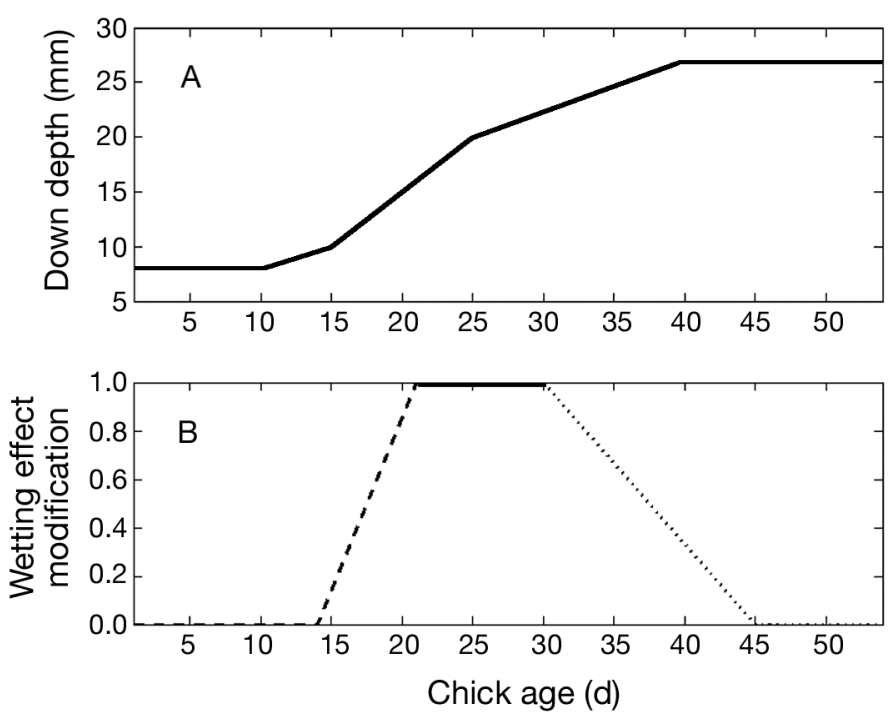

Fig. 2. Pygoscelis adeliae. (A) Change in chick down depth with increasing age (Taylor 1986) and (B) changes in the chick wetting effect modification factor that occurs as the chick ages because of decreased guarding by the parent (dashed line) and as the chick develops fledgling down (dotted line). A chick with a chick wetting modification of 1.0 (solid line, between Days 20 and 30) feels the full wetting effect and is most vulnerable to this thermo-dynamic process where $Q_{\mathrm{e}}$ is the evaporative heat loss rate $\left(\mathrm{W} \mathrm{m}^{-2}\right), \rho_{a}$ is the density of air $\left(\mathrm{g} \mathrm{m}^{-3}\right), D$ is the diffusion coefficient (unitless), $q_{\mathrm{s}}$ and $q_{\mathrm{a}}$ are the specific humidity (unitless) values at the skin of the chick (assuming saturation at the skin temperature) and in the ambient air, respectively, and $H_{\text {evap }}$ is the latent heat of evaporation ( $\mathrm{W} \mathrm{g}^{-1}$ ).

Calculation of thermoregulatory cost of wetting. The thermoregulatory cost of wetting is calculated by first determining the ratio $(W)$ of heat conducted through the skin/feather complex of a wet chick to that of a dry chick:

$$
W=\frac{Q_{\mathrm{r}}(\text { wet })+Q_{\mathrm{s}}(\text { wet })+Q_{\mathrm{x}}(\text { wet })+Q_{\mathrm{e}}(\text { wet })}{Q_{\mathrm{r}}(\text { dry })+Q_{\mathrm{s}}(\text { dry })+Q_{\mathrm{x}}(\text { dry })+Q_{\mathrm{e}}(\text { dry })}-1
$$

The wetting effect ( $\left.W_{\text {effect }}\right)$ is then calculated as:

$$
W_{\text {effect }}=P_{\text {wet }} \cdot W_{\mathrm{m}} \cdot W
$$

where $P_{\text {wet }}$ is the percent of the chick that is wet, $W_{\mathrm{m}}$ is a wetting effect modification provided by a guarding adult or the chick's waterproof fledgling down, and $W$ scales these effects. The wetting effect modification varies between 0 and 1 (Fig. 2B). The reduction of the wetting effect by the guarding adult decreases after Day 14 when the adult can no longer insulate the chick from increased metabolic costs due to the wetting effect. The benefit from the guarding adult is gone at Day 21 when the chick enters the crèche stage and is no longer guarded by adults at the nest. The chick regains protection from wetting between Days 35 and 50 as fledgling plumage develops. Thus, chicks are most vulnerable to wetting between ages 17 and $40 \mathrm{~d}$ (Fig. 2B). There is some evidence that chicks huddle during cold weather, perhaps to reduce their thermoregulatory costs (Lawless et al. 2001). Although the metabolic benefits of huddling has been demonstrated broadly among endotherms (Gilbert et al. 2010), huddling is of uncertain importance to penguin thermoregulation and is likely to have little benefit in smaller colonies where the potential for huddling is limited. The thermoregulatory benefit of huddling among penguin chicks deserves future research, but for now it has been left out of this model.

The wetting effect obtained from Eq. (13) modifies the field metabolic rate (FMR) experienced by the chick as:

$$
\mathrm{FMR}_{\text {wet }}=W_{\text {effect }} \cdot \mathrm{FMR}
$$

where $F M R_{\text {wet }}$ is the increase in the total metabolic cost caused by wetting. The value for $\mathrm{FMR}_{\text {wet }}$ is then added to FMR to calculate the total metabolic costs of the chick.

Summary of meteorological data (see Appendix 2 for sources). Meteorological data used in the calculations include air temperature, wind speed, humidity, 
and solar radiation. A relatively large number of days with high winds during the nestling period occurred during 1995, 1998, 1999, and 2001 (Table 2). During the period when chicks were most vulnerable to the wetting effect (chicks aged 17 to $40 \mathrm{~d}$ ), a relatively large number of days with high winds occurred in 1998, 1999, and 2001 (Table 2). Low temperatures were experienced during the nestling period for a relatively large number of days during 1999, 2001, and 2004 (Table 2). A larger than average number of cold days occurred during 1999 and 2004 at a time when the chicks were most vulnerable to the wetting effect (Table 2).

The 1995 weather conditions are an example of typical intra-nestling period variability in wind and temperature variability. The modified wind data from 1995 (Fig. 3A) show 6 wind events (consisting of consecutive days with high winds) which lasted a total of $10 \mathrm{~d}$ and occurred during the $54 \mathrm{~d}$ chick growth period (Table 2). Two of these wind events occurred during the period when chicks were most vulnerable to the wetting effect (chicks aged 17 to $40 \mathrm{~d}$ ). The ambient temperature averaged $1.0^{\circ} \mathrm{C}$ during the chick growth period, ranging between -1.8 and $3.3^{\circ} \mathrm{C}$ (Fig. 3B). Relative humidity averaged $95 \%$ and ranged between 77 and $100 \%$ (Fig. 3C).

Wetting effect simulations. Three sets of simulations were used to examine the wetting effect. First, a simulation using the 1995 chick rearing period was used to examine the wetting effect in detail. Next, the effect on fledging mass of inter-annual variability in weather was investigated by running simulations using meteorological data during the nestling period between 1995

Table 2. Total days with high winds (mean $>6 \mathrm{~m} \mathrm{~s}^{-1}$ ) and low ambient temperatures (mean $<0^{\circ} \mathrm{C}$ ) during the $54 \mathrm{~d}$ Pygoscelis adeliae nestling period (NP, 19 December to 10 February) and when chicks are most vulnerable to the metabolic costs associated with the wetting effect (chick vulnerability period [CVP], chicks aged 17 to $40 \mathrm{~d}, 4$ to 17 January). Mean daily wind speed and temperatures were obtained from records collected at Faraday/Vernadsky Research station from 1995 to 2004

\begin{tabular}{|c|c|c|c|c|}
\hline \multirow[t]{2}{*}{ Year } & \multicolumn{2}{|c|}{ Days with high winds } & \multicolumn{2}{|c|}{ Days with low temp. } \\
\hline & NP & CVP & NP & CVP \\
\hline 1995 & 10 & 3 & 11 & 3 \\
\hline 1996 & 5 & 3 & 11 & 4 \\
\hline 1997 & 2 & 0 & 11 & 4 \\
\hline 1998 & 10 & 7 & 7 & 4 \\
\hline 1999 & 14 & 6 & 29 & 16 \\
\hline 2000 & 1 & 0 & 1 & 0 \\
\hline 2001 & 17 & 5 & 13 & 3 \\
\hline 2002 & 2 & 1 & 1 & 0 \\
\hline 2003 & 8 & 3 & 5 & 2 \\
\hline 2004 & 7 & 1 & 25 & 12 \\
\hline
\end{tabular}

and 2004. Finally, simulations were done as a sensitivity analysis to examine the effect on chick fledging mass of variability among a subset of poorly understood wetting effect parameters (Table 1). While the influence of variability in each parameter was tested, all other parameters were held constant at base levels (Table 1). Because chicks that become wet from puddles of snow-melt are often continually wet, the proportion of the down that is wet and the proportion of the chick that is wet remain constant within each simulation. As with the altered provisioning schedule simulations, a base provisioning rate for all krill that produced a chick large enough to recruit (RFM) was used for the chick wetting simulations.

Processes not included in the model. Model structure was developed to include the essential information required to model chick growth. Some processes were not included because there was insufficient information to parameterize them, or they were deemed unnecessary for the purposes of the present study. For example, Antarctic fish lipid content, and therefore energy density, may vary seasonally as is observed with Antarctic krill (see references in Chapman et al. 2009). However, seasonality in fish lipid content has not been studied and was not included in this model. Nevertheless, seasonal variability in lipid content among fish populations, and differences in this seasonality with respect to that of Antarctic krill, may have important implications for chick growth. For example, fish may be a relatively high-quality prey item following krill spawning (often during the nestling period off the WAP; Spiridonov 1995) when mature female Antarctic krill lose $54 \%$ of their lipid (Clarke 1980).

Heat stress is an additional process not included in the model, that may influence chick growth and fledging mass. Adélie penguin chicks are vulnerable to even short periods during which temperatures exceed 20 to $25^{\circ} \mathrm{C}$ (Chappell et al. 1990). While Adélie penguins at Anvers Island rarely experience these temperatures (Chappell et al. 1990), even short periods of elevated temperatures cause increased metabolic costs due to panting and other behavioral mechanisms for increasing the flux of heat away from the chick. Although the increase in warming off the wAP is largely due to increases in winter temperatures (Turner et al. 2005a), it is likely that these periods of elevated temperatures during penguin chick-rearing are increasing with the warming of the wAP climate. The influence of warming temperatures on heat stress processes that could result in reduced growth, or even chick death, has not been studied. Including heat stress in the model would introduce too much uncertainty, so it was omitted. Future work on the frequency and metabolic cost of heat stress among Adélie pen- 

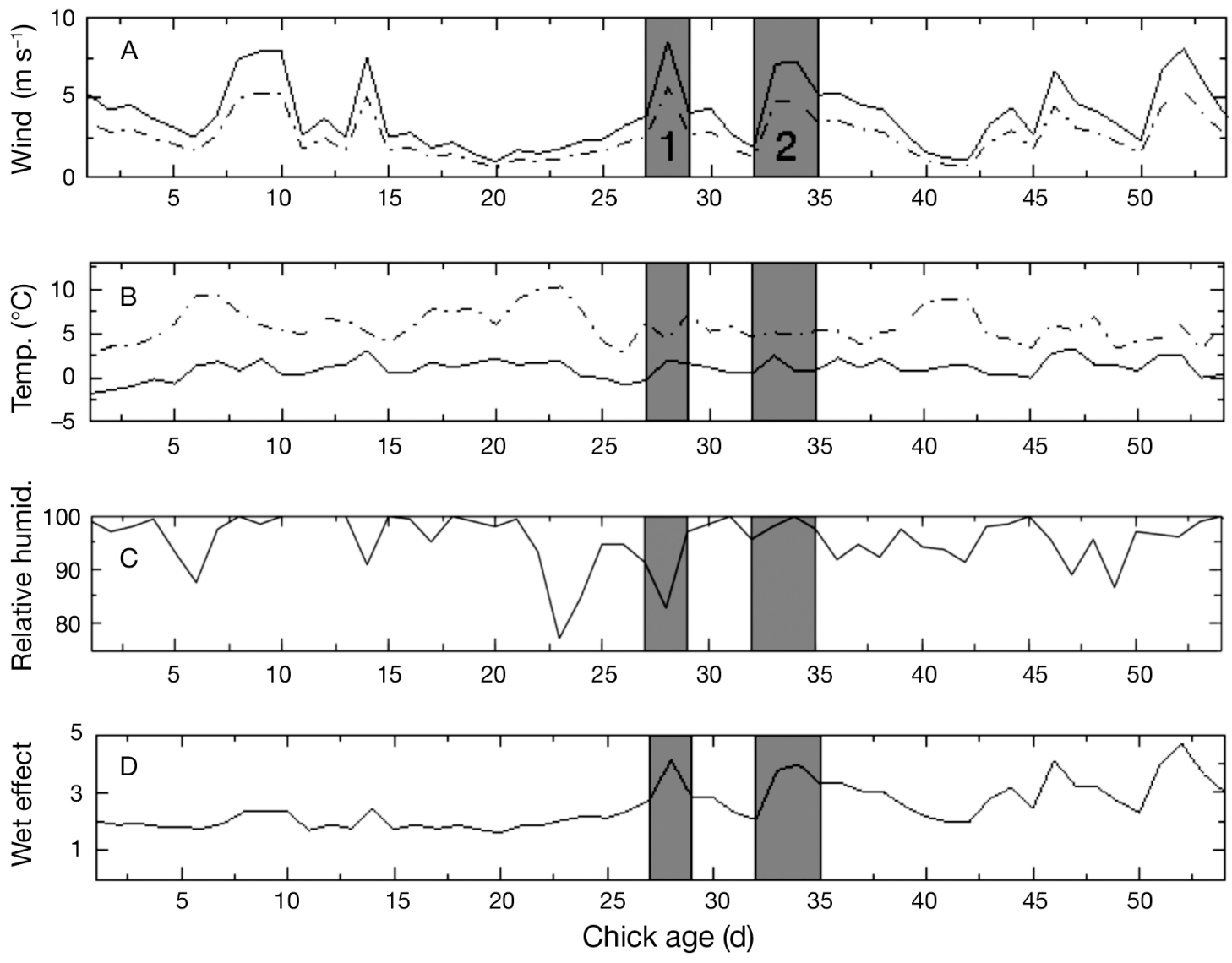

Fig. 3. Pygoscelis adeliae. Time series measured in 1995 at Faraday (UK)/Vernadsky (Ukraine) meteorological station during the chick nestling period of: (A) wind speed (solid line, $\mathrm{m} \mathrm{s}^{-1}$ ) and wind speed adjusted for chick height (dot-dashed line), (B) ambient air temperature (solid line) and operative temperature (dot-dashed line, $T_{\mathrm{e}}{ }^{\circ} \mathrm{C}$ ), $(\mathrm{C})$ relative humidity (unitless), and (D) the calculated wet effect, or the ratio between wet and dry thermal conductance ( $W$, unitless). The shading indicates 2 high-wind events (daily wind speed $>6 \mathrm{~m} \mathrm{~s}^{-1}$ ) during the nestling period, when chicks were most vulnerable to the wetting effect (chicks aged 17 to $40 \mathrm{~d}$ )

guin chicks would enable modeling of this process within a chick growth model. Warming is also likely to have some beneficial thermoregulatory impacts that are not modeled here, though this benefit is likely to be small given that the absolute rise in temperatures off the wAP has been small $\left(0.56^{\circ} \mathrm{C}\right.$ decade ${ }^{-1}$; Turner et al. 2005a).

The influence of water on operative temperature, variability in chick body temperature, and potential compensatory mechanisms for poor chick growth by the adult (e.g. increased provisioning rate) were not considered and may have some influence on model results. The model also does not account for some physiological processes that are important for chick growth and survival, such as chick nutrient- or waterbalance. Also, a detailed comparison of the insulating structures and properties of chick down would improve estimations in this model that were based on the downy after-feather of an adult feather. Finally, differences in the amount of wetting effect heat loss caused by what part of the chick is wet were also not considered.

\section{RESULTS}

\section{Fish simulations}

Adélie penguin Pygoscelis adeliae chicks raised on a fish/krill mixed diet consisting of AC0 or AC1 Antarctic silverfish Pleuragramma antarcticum and Antarctic krill Euphausia superba reach a simulated fledging mass of (AC0) 2.76 and (AC1) $2.90 \mathrm{~kg}$ (Fig. 4A). These fledging masses are less than the NRFM for chicks fed a krill-only diet. Chicks reared on AC2 Antarctic silverfish combined with Antarctic krill reached a simulated fledging mass equivalent to that obtained for a krill-only diet (Fig. 4A). Adding AC3 and AC4 Antarctic silverfish to an all-krill diet increased fledging mass by 5 and $6 \%$, respectively, to a mass above the RFM (Fig. 4A). 

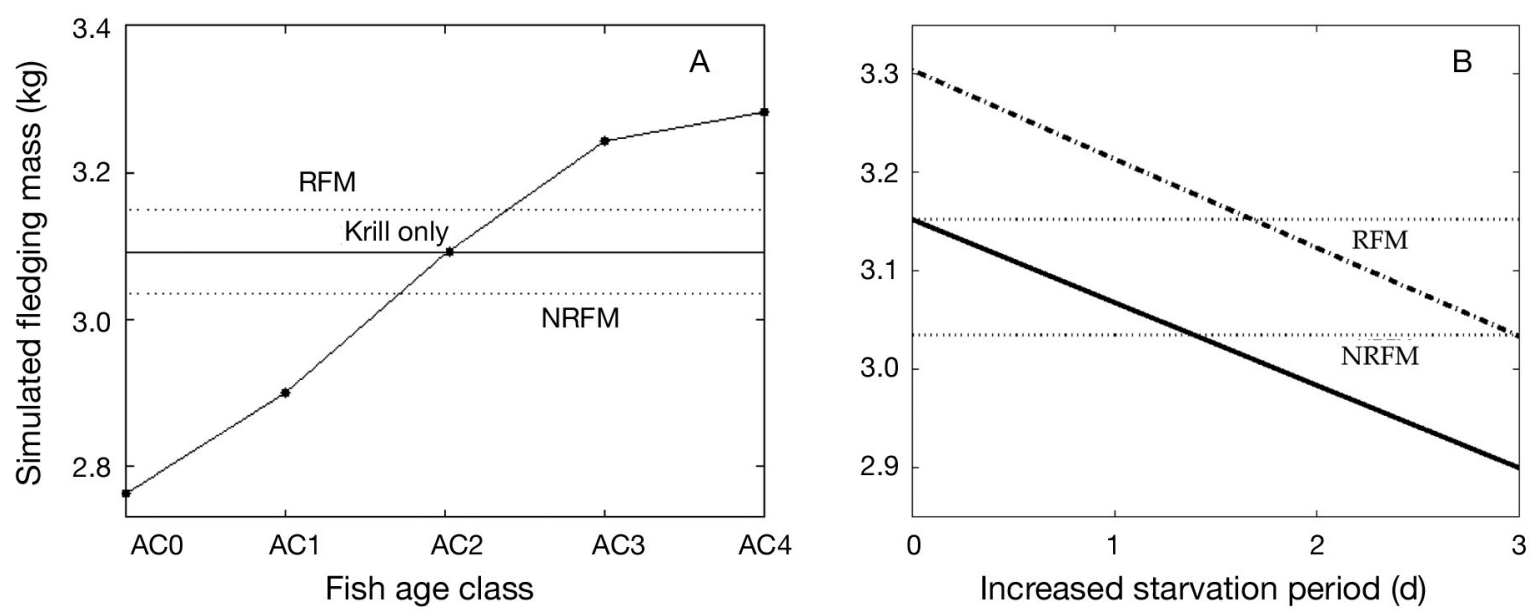

Fig. 4. Pygoscelis adeliae. (A) Simulated fledging mass for a chick raised on a mixed diet of krill and Antarctic silverfish Pleuragramma antarcticum (solid curve) of age-classes (AC) 0 through 4 . The simulated fledging mass for chicks raised on an all-krill Euphausia superba diet is also indicated (horizontal solid line). Simulated chick fledging mass obtained with: (B) increasing length of the chick starvation period and (C) variability in the chick provisioning rate. Simulated fledging mass was obtained for an all-krill diet (solid line) and a combined diet of Antarctic krill and AC3 Antarctic silverfish (dotdashed line). In all panels, mean fledging mass of tagged chicks that recruited into the breeding population at Palmer Station (re-sighted fledge mass, RFM) and the mean mass of banded chicks that did not recruit (not re-sighted fledge mass, NRFM) are indicated (horizontal dotted lines)

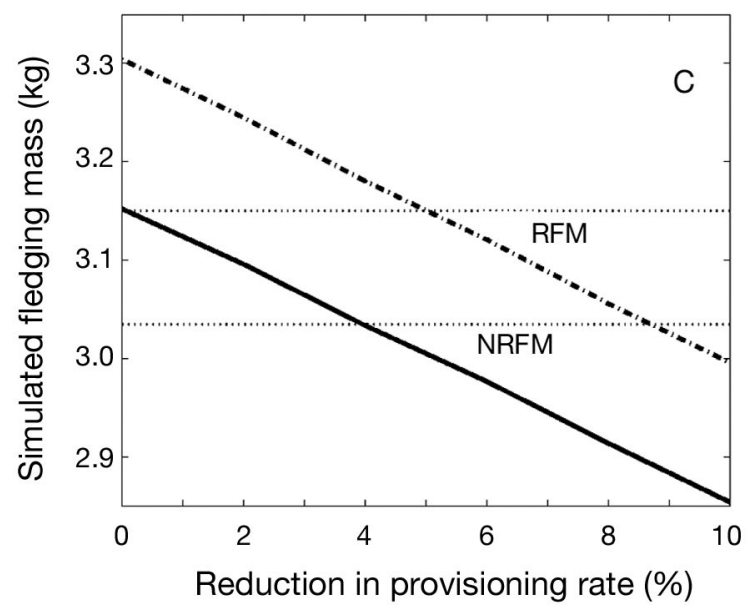

\section{Provisioning schedule simulations}

\section{Increased chick starvation period}

For the krill-only diet, increased duration of the starvation period resulted in a significant decrease in chick fledging mass (Fig. 4B). Lengthening the starvation period to $3 \mathrm{~d}$ reduced the krill delivered to the chick by $2.52 \mathrm{~kg}$. Increasing the starvation period by $>1 \mathrm{~d}$ decreased the simulated fledging mass sufficiently to reduce the chick's probability for recruitment. For the diet including Antarctic silverfish, increasing the duration of the starvation period to $3 \mathrm{~d}$ decreased the simulated fledging mass from $3.30 \mathrm{~kg}$ to below the NRFM (Fig. 4B).

\section{Reduced chick provisioning rate}

Simulated fledging mass decreased proportionally from the RFM to $2.90 \mathrm{~kg}$ as the reduction in provisioning rate increased from 0 to $10 \%$ (Fig. 4C). With a

reduction of $>4 \%$ of the reference provisioning rate, the simulated fledging mass fell below the NRFM. For the diet including Antarctic silverfish, fledging mass decreased from 3.30 to $3.00 \mathrm{~kg}$ as the percentage reduction in provisioning rate increased from 0 to $10 \%$ (Fig. 4C). The simulated fledging mass fell below the NRFM when the diet was reduced by $>8 \%$.

\section{Chick wetting simulations}

The modeled variability of the wetting effect during the nestling period is illustrated by a simulation using the 1995 conditions. For this year, the wetting effect $(W)$ in the model was 2.5 on average and peaked during 4 high wind events to a value > 3.5 (Fig. 3D). These values are remarkably similar to the measured value for $W$ for wet gentoo penguin chick pelts $(2.8$; Kooyman et al. 1976), providing support for the methods used to calculate the wetting effect in the present study. The limited available research suggests that the ratio of wet to dry thermal conductivity ( $W$, here) for 
adult bird pelts is lower at 1.1 for barn owls Tyto alba (McCafferty et al. 1997) and ranges between 1.1 and 1.8 for adult pygoscelid penguins (Kooyman et al. 1976). Thus, calculations here suggest that downy chicks are more vulnerable to the wetting effect than adults.

Two high-wind events occurred when chicks were most vulnerable to the wetting effect (Fig. 3A,D). The ratio of the modeled wet to dry thermal conductance was most closely correlated with wind speeds (Spearman's rank correlation, $\mathrm{r}^{2}=0.70, \mathrm{p}<0.001$ ), followed by temperature experienced by the chick (Spearman's rank correlation, $\left.\mathrm{r}^{2}=-0.31, \mathrm{p}=0.023\right)$; the ratio was not related to specific humidity (Spearman's rank correlation, $\mathrm{r}^{2}=0.17, \mathrm{p}=0.21$ ).

Generally, the greatest chick heat loss, as modeled, was from conductive heat flux, followed by convective, latent, and then radiative heat flux (Fig. 5A). There was a sharp decrease in the total metabolic costs caused by wetting after the guard stage (chicks aged $\sim 21 \mathrm{~d})$ as the chick's down grew deeper. Variability in conductive heat loss was relatively high and appeared to be more strongly correlated with the variability in total wetting heat loss than other heat loss modes. During the 2 high wind events during the period when chicks were most vulnerable to the wetting effect, the heat flux due to convection surpassed that due to conductive heat loss and became the mode of heat loss most responsible for the wetting effect (Fig. 5A).

The modeled wetting effect increased to about 0.12 on Day 26 during the 1995 simulation, as the adult penguin provided less protection from the elements (Fig. 5B). After the guard period ended and prior to the development of fledgling plumage, the extent to which wetting increased the chick's metabolic costs was determined to a large degree by local wind speed. For example, the wetting effect reached 0.21 on Day 28 as a result of the first high wind event (Fig. 5B). A subsequent increase in the wetting effect to 0.15 on Day 33 was associated with the second wind event (Fig. 5B). Following these wind events, the wetting effect returned to zero when the fledgling plumage was fully developed. These short-term increases in the wetting effect had a slight, but noticeable temporary effect on chick growth, although these effects to not appear to have had an important influence on chick mass at the
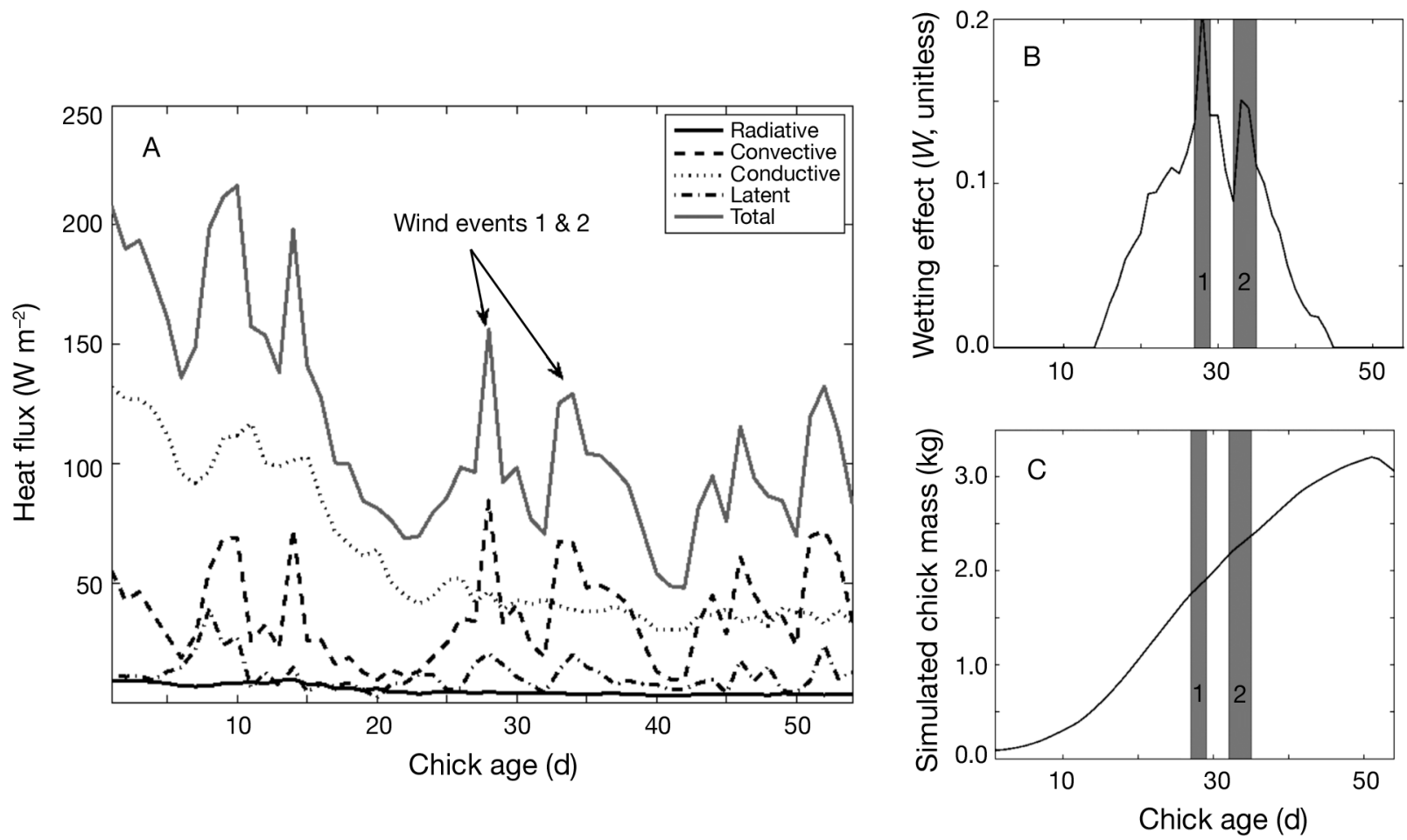

Fig. 5. Pygoscelis adeliae. (A) Total increase in heat flux $\left(\mathrm{W} \mathrm{m}^{-2}\right)$ through the chick's skin/feather complex because of wetting, and the increase for each mode of heat flux for the 1995 nestling period. The increase in heat flux does not take into consideration modification for a guarding parent and development of fledgling plumage. (B) Wetting effect $(W$ ) as a function of chick age calculated using the 1995 meteorological time series for the Adélie penguin breeding season. (C) Simulated chick fledging mass obtained for 1995 meteorological conditions during the chick nestling period using base values for the wetting parameters (Table 1). In all panels, the 2 wind events that occurred during the period when chicks were most vulnerable to the wetting effect (chicks aged 17 to $40 \mathrm{~d}$ ) are labelled, or indicated by shading 


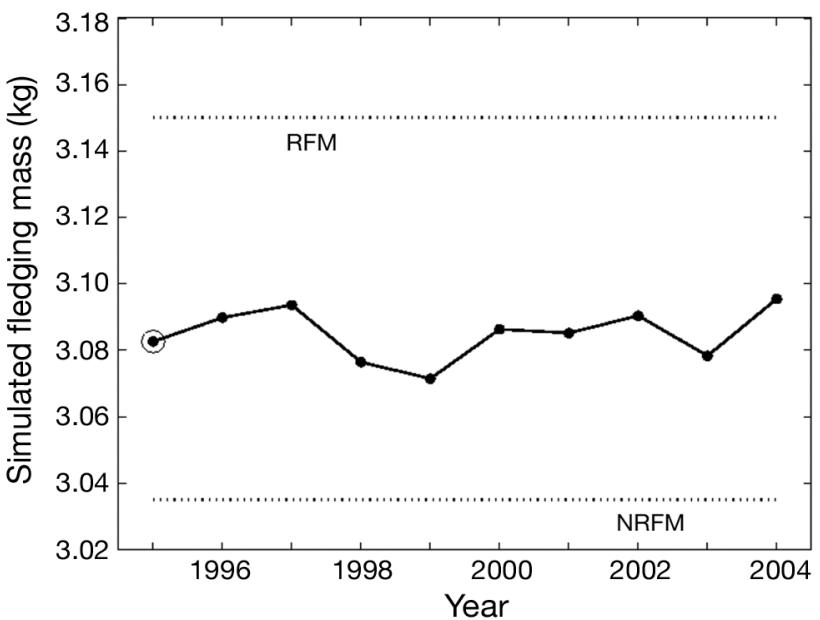

Fig. 6. Pygoscelis adeliae. Simulated fledging mass obtained using the base case wetting parameters (Table 1) and the 1995 to 2004 meteorological time series for the chick nestling periods. The 1995 fledging mass, which provides a reference simulation, is circled. Mean fledging mass of tagged chicks that recruited into the breeding population at Palmer Station (re-sighted fledge mass, RFM) and mean mass of banded chicks that did not recruit (not re-sighted fledge mass, NRFM) are indicated end of the nestling period (Fig. 5C). Growth slowed from 101 to $77 \mathrm{~g} \mathrm{~d}^{-1}$ during Wind Event 1 and from 89 to $64 \mathrm{~g} \mathrm{~d}^{-1}$ during Wind Event 2, which contributed to the overall reduction in fledging mass.

The simulated fledging mass obtained under equal food supply and quality and variable environmental conditions (driven by a time series of meteorological conditions between 1995 to 2004 for Adélie penguin chicks on Anvers Island) ranged from 3.07 (1999) to $3.09 \mathrm{~kg}$ (2004), with an overall mean of $3.08 \mathrm{~kg}$ (Fig. 6). These years span a wide range of environmental conditions (Table 2), yet there was little variability among simulated fledging mass and none fell below the NRFM. Inter-annual variability in simulated fledging mass was most sensitive to the number of windy and cold days during the period when chicks were most vulnerable to the wetting effect (Fig. 6). Specifically, simulated fledging mass was lowest under 1999 weather conditions (Fig. 6) when there were more days with high wind speeds and low temperatures during the period when chicks are most vulnerable to the thermoregulatory costs of wetting. Wind appears to be the more important meteorological variable, however, as the sec-
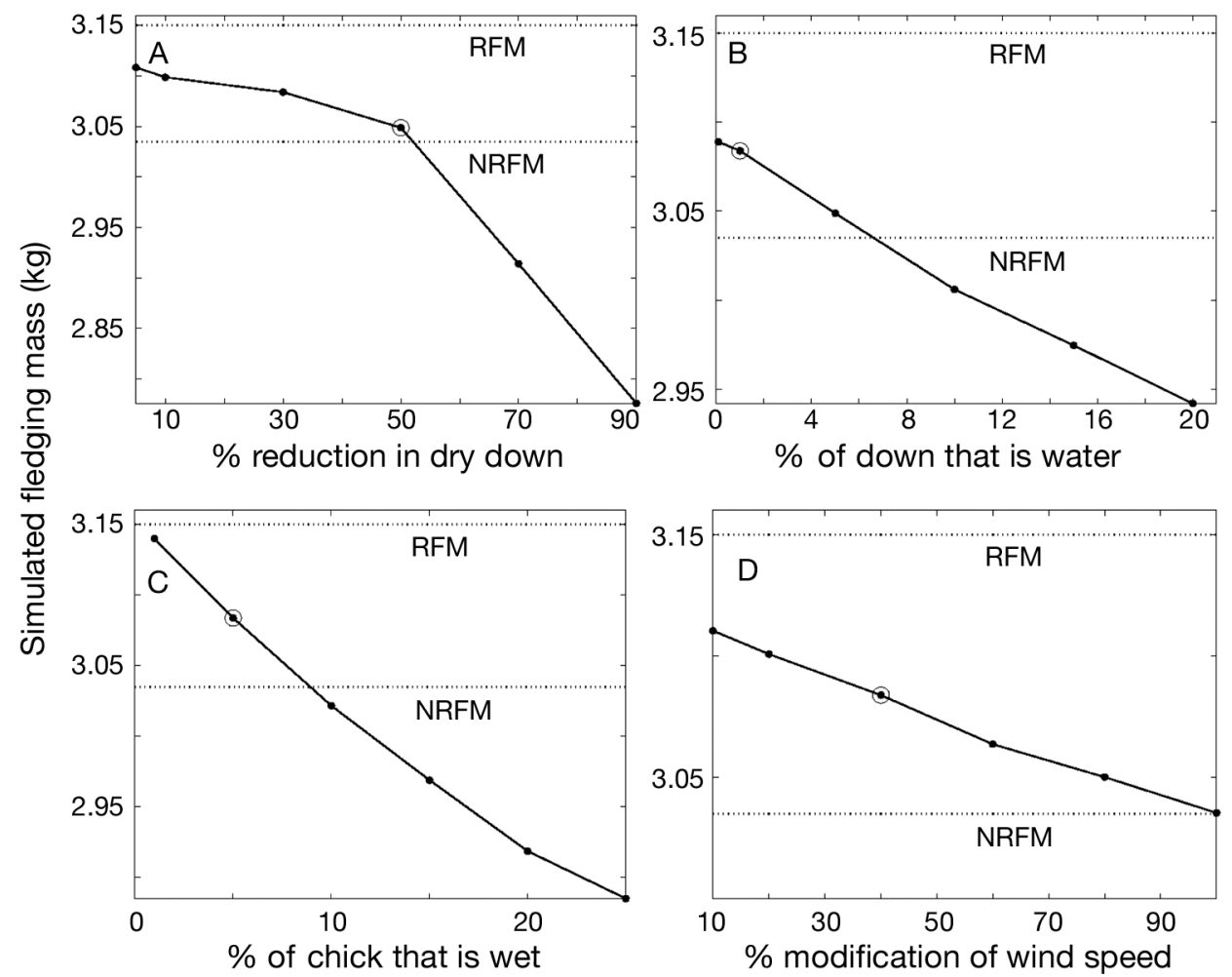

Fig. 7. Pygoscelis adeliae. Simulated fledging mass obtained from variability in (A) the percent reduction in down depth by water, (B) the percentage of the down structure that is composed of water, (C) the percentage of the chick that is wet, and (D) the percent modification of wind speed to generate the effective wind speed acting on heat transfer away from the chick. Mean fledging mass of tagged chicks that recruited into the breeding population at Palmer Station (re-sighted fledge mass, RFM) and mean mass of chicks that did not recruit (not re-sighted fledge mass, NRFM) are indicated. Simulated fledging mass at the parameter value used for the reference simulation (1995 conditions) is indicated by a circle 
ond lowest simulated fledging mass occurred in 1998 (Fig. 6), when there were more windy days, but a moderate number of days when temperatures were low (Table 2). The highest simulated fledging mass occurred in 2004 (Fig. 6), when there were few windy days but many cold days during the period when chicks were most vulnerable to wetting effects (Table 2).

Sensitivity simulations found that increasing the parameter for the percent modification of dry down depth by water decreased simulated fledging mass (Fig. 7A). Just over a 50\% reduction in dry down depth by water reduced simulated fledging mass to the NRFM. As more water was retained in the chick's down (e.g. the chick becomes saturated), fledging mass decreases (Fig. 7B). Wetting only 8 to $10 \%$ of the chick was sufficient to reduce the fledging mass below the NRFM (Fig. 7C). Variability in the wind modification parameter had less of an effect on chick fledging mass than did variability in the percent of the chick that was wet (Fig. 7D). For all values of the wind modification parameter, chick fledging mass remained between the RFM and the NRFM.

As with the provisioning schedule simulations, we expected the wetting simulations to produce smaller chicks, and a reference scenario that produced a chick with a fledging mass of $3.15 \mathrm{~kg}$, the RFM, was used.

\section{Combined effect of adding fish and chick wetting}

The mixed diet simulations showed that adding AC3 and older Antarctic silverfish to an all-krill diet increases chick fledging mass. Therefore, diet is one factor that can potentially offset the effects of increased thermoregulatory costs due to wetting of the chick. To test the combined effect of diet and wetting on chick growth, additional simulations were done in which the percent of the chick that is wet ( 0 to $25 \%$ ) and the percentage of the diet composed of AC3 Antarctic silverfish (0 to $50 \%$ ) were varied (Fig. 8).

For chicks that are $<10 \%$ wet, simulated fledging mass that corresponded to chicks with a higher probability of survival (RFM, $3.15 \mathrm{~kg}$ ) can be obtained with a krill-only and mixed krill and Antarctic silverfish diet. However, as wetting increased from $10 \%$, an increasing proportion of fish was needed in the diet to compensate for thermoregulatory losses. Offsetting a $5 \%$ increase in wetting required that a chick be provided with a diet consisting of about $10 \%$ AC3 Antarctic silverfish. A chick that was $15 \%$ wet needed a diet that included almost 25\% AC3 Antarctic silverfish to maintain a fledging mass of $3.15 \mathrm{~kg}$ (Fig. 8). Thus, switching to a more Antarctic silverfish-based diet can potentially mitigate thermoregulatory effects of increased wetting on Adélie penguin chick growth.

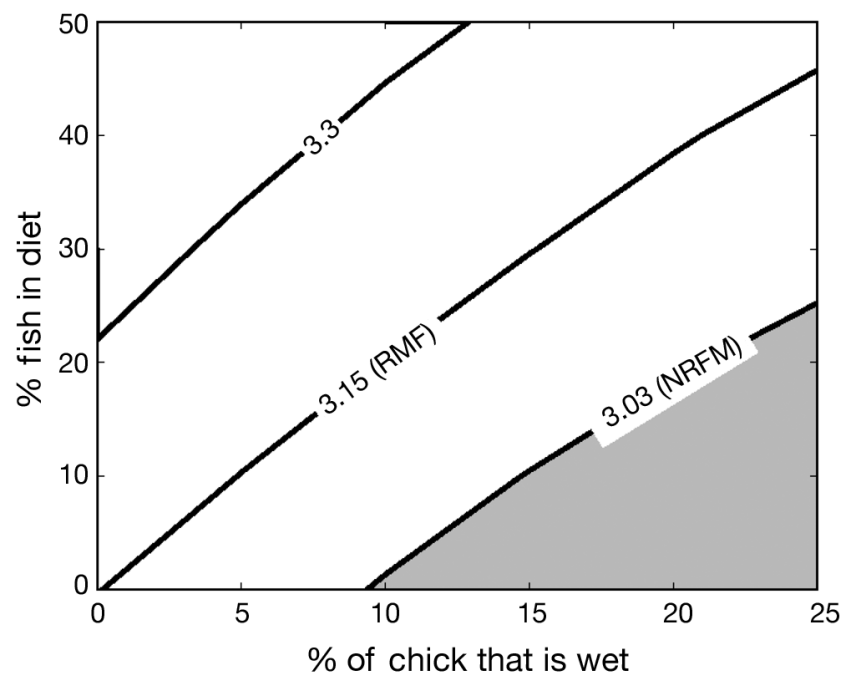

Fig. 8. Pygoscelis adeliae. Simulated chick fledging mass (kg) resulting from variability in the percent of the chick that is wet and the proportion of AC3 Antarctic silverfish Pleuragramma antarcticum in the chick diet. The simulated chick fledging mass that equals the mean mass of fledging chicks that are resighted (re-sighted fledge mass, RFM, $3.15 \mathrm{~kg}$ ) and not resighted and presumably do not recruit into the breeding population (not re-sighted fledge mass, NRFM, $3.03 \mathrm{~kg}$ ) are indicated. Simulated fledging masses below the NRFM are shaded

\section{DISCUSSION AND SUMMARY}

\section{Importance of fish in the chick diet}

The models provide insights into several processes that have implications for Adélie penguin Pygoscelis adeliae reproductive energetics in light of future climate projections. Furthermore, our results point to several areas where additional field research could move our understanding forward regarding the influence of climate on Adélie penguin reproductive success and population trajectory.

Due to differences in energy density, given equal provisioning rates, supplementing an Antarctic krill Euphausia superba chick diet with Antarctic silverfish Pleuragramma antarcticum of at least AC3 produces simulated chicks that are heavier and more likely to recruit than those fed an all-krill diet. A reduction in the quality of available prey can have severe negative implications for top-predator populations (Osterblom \& Olsson 2008). The absence of Antarctic silverfish from Adélie penguin diets near Anvers Island and over the entire mid- to northern wAP (Fraser \& Trivelpiece 1996, Hinke et al. 2007) may have led to lower quality (energy content) chick diets making it more difficult for adult Adélie penguins to produce chicks that will recruit. 
The extent to which this alternative prey source contributes to chick growth is presumably determined by environmental conditions that influence the fish's distribution. Antarctic silverfish disappeared from Adélie penguin diets about $200 \mathrm{yr}$ ago in several regions of the Antarctic, including some regions of the wAP (Emslie \& Patterson 2007). Antarctic silverfish from 95 to $117 \mathrm{~mm}$ in length were the most prominent fish in Adélie penguin diets off the wAP $>200 \mathrm{yr}$ ago (McDaniel \& Emslie 2002); the length of these fish corresponds to the energy-rich AC4 and older Antarctic silverfish. The cause for the loss of Antarctic silverfish is unclear. It has been suggested that Antarctic silverfish declined in response to increased competition from surging krill populations following removal of large whales and seals at the turn of the century (Emslie \& Patterson 2007), though climate reconstructions suggest a generally cooler than normal climate from 200 to 50 yr before the present (Schneider et al. 2006), which may have favored Antarctic silverfish populations that require ice for spawning (Kellermann 1987, Bottaro et al. 2009). Regardless of the cause, the loss of Antarctic silverfish from the wAP required some adjustment by the Adélie penguin to a lower quality diet in order to raise viable chicks. Possible adjustments include increasing feeding rates or altering foraging behavior to focus on high-energy density Antarctic krill (i.e. gravid females). While breeding Adélie penguins may have some capacity to adjust to the loss of Antarctic silverfish from their diets, ultimately the loss of older ageclasses of this high-energy prey item likely leaves these penguins less resilient to environmental change.

Overall, environmental conditions that alter sea ice concentration and extent, combined with an increasing population of fish- and krill-eating whale species (Branch 2006), may potentially alter the availability of 2 of the primary prey resources that are needed to raise Adélie penguin chicks.

\section{Effect of an altered feeding schedule}

Following breeding, adult Adélie penguins gain weight (Ainley 2002) as they face the energetic cost of molting followed by an extended period of reduced (and/or patchier) prey availability and perhaps lower prey quality during the winter. Therefore, factors that cause a delay in the breeding schedule (e.g. delayed laying date due to increased snowfall in colonies) may require that adults switch their efforts prematurely from chick provisioning to self-maintenance, increasing the chick starvation period. The simulations in the present study suggest that conditions that cause an increase in the starvation period, even of just $1 \mathrm{~d}$, can change the amount of energy that a chick receives from the adult and compromise chick growth sufficiently to affect the probability of recruitment.

Any factor that causes even a slight reduction in provisioning rate could have a considerable impact on fledging mass and recruitment. Factors such as adult age/experience (Ainley 2002), adult body condition (Tveraa et al. 1998), prey availability (Clarke et al. 2002), increased foraging costs (Watanuki et al. 2002, Takahashi et al. 2003), and the number of chicks in a brood (Ainley \& Schlatter 1972) affect the provisioning rate of chicks by the adult. Adults may use complex foraging strategies that alternate long- and short-duration foraging trips to meet their own and their chick's energy requirements, respectively (Ropert-Coudert et al. 2004). However, in general, adult Adélie penguins and other long-lived seabirds preserve their own condition at the cost of their chicks when environmental stress occurs (Tveraa et al. 1998, Watanuki et al. 2002, Takahashi et al. 2003). Therefore, under environmental stress affecting penguin foraging success, an adult is likely to provide less energy to their $\operatorname{chick}(\mathrm{s})$. One such stress may be reduced prey availability due to the added foraging pressure of other top predators (e.g. whales, Branch 2006; seals, Siniff et al. 2008; chinstrap and gentoo penguins, Ducklow et al. 2007) that have increased in abundance at Anvers Island during the nestling period. Predation pressure on the mid-trophic level can reduce the availability of fish and krill to breeding Adélie penguin colonies (Ainley et al. 2006), which may have important implications for provisioning rate and chick growth off the wAP, but these effects are not well understood in this region. However, the presence of older Antarctic silverfish as a prey item could compensate for environmental stressors that cause a reduction in provisioning rate.

\section{Effects of chick wetting at the nest}

Adélie penguin chicks can maintain their body temperatures within a broad range of environmental temperatures and wind speeds (Taylor 1986, Chappell et al. 1989), but their ability to do so under wet conditions is unknown. Simulations suggest that environmental conditions that result in sustained or increased wetting of chick down, such as extensive snow-melt or excessive rain, may adversely affect chick growth and survivorship, potentially leading to reduced recruitment and a declining population. Given that precipitation is projected to increase off the wAP with regional warming (Ainley et al. 2010) and that Adélie penguins are typically found in dry regions of the Antarctic (Ainley 2002), these effects may become increasingly important. The effects of wetting may be particularly detrimental in smaller colonies, where the thermoregulatory benefit of huddling behavior during the crèche stage (Lawless et 
al. 2001), when chicks are most vulnerable to this metabolic cost, is limited. It is possible that under favorable foraging conditions, adult penguins are able to compensate for the wetting effect by increased provisioning to wet chicks, although this has not been documented.

Acknowledgements. We thank B. Salihoglu for providing the original framework for the chick growth model. We also thank the Palmer Station support staff for facilitating our long-term data collection efforts. Furthermore, we are grateful for the assistance provided by many field team members who have helped with data collection over the years. We thank David Ainley and 4 anonymous reviewers for their comments which greatly improved the present paper. This research was funded through National Science Foundation Grants ANT0323254, OPP-9011927, OPP-9605596, OPP-0130525, OPP0217282, OPP-0224727, and OPP-052361. The development of the penguin chick growth model was supported by National Science Foundation Grant ANT-0523254 and is part of the U.S. Southern Ocean Global Oceans Ecosystem Dynamics synthesis and integration phase.

\section{LITERATURE CITED}

Ainley DG (2002) The Adélie penguin: bellwether of climate change. Columbia University Press, Columbia, NY

Ainley D, Schlatter R (1972) Chick raising ability of Adélie penguins. Auk 89:559-566

Ainley DG, Wilson PR, Barton KJ, Ballard G, Nur N, Karl B (1998) Diet and foraging effort of Adélie penguins in relation to pack-ice conditions in the southern Ross Sea. Polar Biol 20:311-319

Ainley DG, Ballard G, Barton KJ, Karl BJ, Rau GH, Ribic CA, Wilson PR (2003) Spatial and temporal variation of diet within a presumed metapopulation of Adélie penguins. Condor 105:95-105

Ainley DG, Ballard G, Dugger KM (2006) Competition among penguins and cetaceans reveals trophic cascades in the western Ross Sea, Antarctica. Ecology 87:2080-2093

Ainley D, Ballard G, Ackley S, Blight L and others (2007) Paradigm lost, or is top-down forcing no longer significant in the Antarctic marine ecosystem? Antarct Sci 19:283-290

Ainley D, Ballard G, Blight L, Ackley S and others (2009) Impacts of cetaceans on the structure of Southern Ocean food webs. Mar Mamm Sci 26:482-498

Ainley D, Russel J, Jenouvrier S, Woehler E, Lyver POB, Fraser WR, Kooyman GL (2010) Antarctic penguin response to habitat change as earth's trophosphere reaches $2^{\circ} \mathrm{C}$ above preindustrial levels. Ecol Monogr 80: 49-66

Atkinson A, Siegel V, Pakhomov E, Rothery P (2004) Longterm decline in krill stock and increase in salps within the Southern Ocean. Nature 432:100-103

Bottaro M, Oliveri D, Ghigliotti L, Pisano E, Ferrando S, Vacchi $M$ (2009) Born among the ice: the first morphological observations of two developmental stages of the Antarctic silverfish Pleuragramma antarcticum, a key species of the Southern Ocean. Rev Fish Biol Fish 19:249-259

Branch TA (2006) Humpback abundance south of $60^{\circ} \mathrm{S}$ from three completed sets of IDCR/SOWER circumpolar surveys. Paper SC/A06/HW6 presented at the International Whaling Commission Scientific Committee Workshop on the Comprehensive Assessment of Southern Hemisphere Humpback Whales, Hobart, April 2006
Cena K, Monteith JL (1975a) Transfer processes in animal coats. I. Radiative transfer. Proc R Soc Lond B Biol Sci 188: 377-393

Cena K, Monteith JL (1975b) Transfer processes in animal coats. II. Conduction and convection. Proc R Soc Lond B Biol Sci 188:395-411

> Cena K, Monteith JL (1975c) Transfer processes in animal coats. III. Water vapour diffusion. Proc R Soc Lond B Biol Sci 188:413-423

Chapman EW, Hofmann EE, Patterson DL, Fraser WR (2009) Variability in Antarctic krill (Euphausia superba) spawning behavior and sex/maturity stage distribution and Adélie penguin (Pygoscelis adeliae) chick growth: a modeling study. Deep-Sea Res II 57:543-558

Chappell MA, Souza SL (1988) Thermoregulation, gas exchange, and ventilation in breeding Adélie penguins (Pygoscelis adeliae). J Comp Physiol B 157:783-790

Chappell MA, Morgan KR, Souza SL, Bucher TL (1989) Convection and thermoregulation in two Antarctic seabirds. J Comp Physiol B 159:313-322

Chappell MA, Morgan KR, Bucher TL (1990) Weather, microclimate, and energy costs of thermoregulation for breeding Adélie penguins. Oecologia 83:420-426

Clarke A (1980) The biochemical composition of krill, Euphausia superba Dana, from South Georgia. J Exp Mar Biol Ecol 43:221-236

> Clarke J, Kerry K, Irvine L, Phillips B (2002) Chick provisioning and breeding success of Adélie penguins at Béchervaise Island over eight successive seasons. Polar Biol 25: $21-30$

Clarke A, Johnston NM, Murphy EJ, Rogers AD (2007) Introduction: Antarctic ecology from genes to ecosystems: the impact of climate change and the importance of scale. Philos Trans R Soc Lond B 362:5-9

Cooper J (1977) Energetic requirements for growth of the jackass penguin. Zoologica Africana 12:201-213

Croxall JP, Reid K, Prince PA (1999) Diet, provisioning and productivity responses of marine predators to differences in availability of Antarctic krill. Mar Ecol Prog Ser 177: 115-131

> Davoren GK, Montevecchi WA (2003) Signals from seabirds indicate changing biology of capelin stocks. Mar Ecol Prog Ser 258:253-261

Dawson C, Vincent JFV, Jeronimidis G, Rice G, Forshaw P (1999) Heat transfer through penguin feathers. J Theor Biol 199:291-295

DeAngelis DL, Mooij WM (2005) Individual-based modeling of ecological and evolutionary processes. Annu Rev Ecol Evol Syst 36:147-168

> Donnelly J, Torres JJ, Hopkins TL, Lancraft TM (1990) Proximate composition of Antarctic mesopelagic fishes. Mar Biol 106:13-23

Ducklow HW, Baker K, Martinson DG, Quetin LB and others (2007) Marine pelagic ecosystems: the West Antarctic Peninsula. Philos Trans R Soc Lond B 362:67-94

Emslie SD, Patterson WP (2007) Abrupt recent shift in ${ }^{13} \mathrm{C}$ and ${ }^{15} \mathrm{~N}$ values in Adélie penguin eggshell in Antarctica. Proc Natl Acad Sci USA 104:11666-11669

Fraser WR, Trivelpiece WZ (1996) Factors controlling the distribution of seabirds: winter-summer heterogeneity in the distribution of Adélie penguin population. In: Foundations of ecological research west of the Antarctic Peninsula. American Geophysical Union, Washington, DC, p 257-272

> Gilbert C, McCafferty D, Le Maho Y, Martrett JM, Giroud S, Blanc S, Ancel A (2010) One for all and all for one: the energetic benefits of huddling in endotherms. Biol Rev Camb Philos Soc 85:545-569 
Gill A (1982) Atmosphere-Ocean dynamics. Academic Press, New York, NY

Grimm V, Railsback SF (2005) Individual-based modeling and ecology. Princeton University Press, Princeton, NJ

> Hagen W, Kattner G, Friedrich C (2000) The lipid compositions of high-Antarctic notothenioid fish species with different life strategies. Polar Biol 23:785-791

Hagen W, Kattner G, Terbruggen A, Van Vleet ES (2001) Lipid metabolism of the Antarctic krill Euphausia superba and its ecological implications. Mar Biol 139:95-104

Hinke JT, Salwicka K, Trivelpiece SG, Watters GM, Trivelpiece WZ (2007) Divergent responses of Pygoscelis penguins reveal a common environmental driver. Oecologia 153:845-855

Hipfner J, Charette M, Blackburn G (2007) Subcolony variation in breeding success in the tufted puffin (Fratercula cirrhata): association with foraging ecology and implications. Auk 124:1149-1157

Hubold G, Hagen W (1997) Seasonality of feeding and lipid content in juvenile Pleuragramma antarcticum (Pisces: Nototheniidae) in the southern Weddell Sea. In: Proceedings of 6th SCAR symposium on Antarctic biology. Cambridge University Press, Cambridge, p 277-283

Hubold G, Tomo AP (1989) Age and growth of Antarctic silverfish Pleuragramma antarcticum Boulenger, 1902, from the Southern Weddell Sea and Antarctic Peninsula. Polar Biol 9:205-212

Hunt GL, Eppley ZA, Schneider DC (1986) Reproductive performance of seabirds: the importance of population and colony size. Auk 103:306-317

Incropera FP, DeWitt DP (1985) Fundamentals of heat and mass transfer. John Wiley \& Sons, New York, NY

Jackson S (1986) Assimilation efficiencies of white-chinned petrels (Procellaria aequinoctialis) fed different prey. Comp Biochem Physiol 85A:301-303

Janes DN (1997) Energetics, growth and body composition of Adélie penguin chicks, Pygoscelis adeliae. J Zool 70: 237-243

Kellermann A (1987) Food and feeding ecology of postlarval and juvenile Pleuragramma antarcticum (Pisces; Notothenioidei) in the seasonal pack ice zone off the Antarctic Peninsula. Polar Biol 7:307-315

Kooyman GL, Gentry RL, Bergman WP, Hammel HT (1976) Heat loss in penguins during immersion and compression. Comp Biochem Physiol A 54:75-80

- Lawless RM, Buttemer WA, Astheimer LB, Kerry KR (2001) The influence of thermoregulatory demand on contact crèching behaviour in Adélie penguin chicks. J Therm Biol 26:555-562

Lustick S, Adams J (1977) Seasonal variation in the effects of wetting on the energetics and survival of starlings (Sturnus vulgaris). J Comp Physiol 56A:173-177

McCafferty DJ, Moncrieff JB, Taylor IR (1997) The effect of wind speed and wetting on thermal resistance of the barn owl (Tyto alba). I. Total heat loss, boundary layer and total resistance. J Therm Biol 22:253-264

McDaniel JD, Emslie SD (2002) Fluctuations in Adélie penguin prey size in the mid to late Holocene, north Marguerite Bay, Antarctic Peninsula. Polar Biol 25: 618-623

Osterblom H, Olsson O, Blenckner T, Furness RW (2008) Junk-food in marine ecosystems. Oikos 117:967-977

Patterson DL, Easter-Pilcher AL, Fraser WR (2003) The effects of human activity and environmental variability on longterm changes in Adélie penguin populations at Palmer Station Antarctica. In: Antarctic biology in a global context. Backhuys Publishers, Kerkwerve, p 301-307
Radtke RL, Hubold G, Folsom SD, Lenz PH (1993) Otolith structural and chemical analyses: the key to resolving age and growth of the Antarctic silverfish, Pleuragramma antarcticum. Antarct Sci 5:51-62

Ropert-Coudert Y, Kato A, Bost CA, Rodary D, Sato K, Maho YL, Naito Y (2002) Do Adélie penguins modify their foraging behaviour in pursuit of different prey? Mar Biol 140: $647-652$

Ropert-Coudert Y, Wilson RP, Daunt F, Kato A (2004) Patterns of energy acquisition by a central place forager: benefits of alternating short and long foraging trips. Behav Ecol 15: 824-830

Salihoglu B, Fraser WR, Hofmann EE (2001) Factors affecting fledging weight of Adélie penguin (Pygoscelis adeliae) chicks: a modeling study. Polar Biol 24:328-337

Schneider DP, Steig EJ, Ommen TD, Bitz CM, Dixon D, Mayewski PA, Jones JM (2006) Antarctic temperatures over the past two centuries, from ice cores. Geophys Res Lett 33:L16707. doi:10.1029/2006GL027057

> Siniff DB, Garrott RA, Rotella JJ, Fraser WR, Ainley DG (2008) Opinion: projecting the effects of environmental change on Antarctic seals. Antarct Sci 20:425-435

Spiridonov V (1995) Spatial and temporal variability in reproductive timing of Antarctic krill (Euphausia superba Dana). Polar Biol 15:161-174

Stammerjohn SE, Martinson DG, Smith RC, Yuan X, Rind D (2008) Trends in Antarctic annual sea ice retreat and advance and their relation to El Niño-Southern Oscillation and Southern Annular Mode variability. J Geophys Res C 113:1-20

Takahashi A, Watanuki Y, Sato K, Kato A, Arai N, Nishikawa J, Naito Y (2003) Parental foraging effort and offspring growth in Adélie penguins: Does working hard improve reproductive success? Funct Ecol 17:590-597

Taylor JR (1985) Ontogeny of thermoregulation and energy metabolism in pygoscelid penguin chicks. J Comp Physiol 155B:615-627

Taylor JRE (1986) Thermal insulation of the down and feathers of pygoscelid penguin chicks and the unique properties of penguin feathers. Auk 103:160-168

Turner J, Colwell SR, Marshall GJ, Lachlan-Cope TA and others (2005a) Antarctic climate change during the last 50 years. Int J Climatol 25:279-294

Turner J, Lachlan-Cope T, Colwell S, Marshall G (2005b) A positive trend in western Antarctic Peninsula precipitation over the last 50 years reflecting regional and Antarcticwide atmospheric circulation changes. Ann Glaciol 41: 85-91

Tveraa T, Saether B, Aenes R, Erikstad KE (1998) Regulation of food provisioning in the Antarctic petrel; the importance of parental body conditions and chick body mass. J Anim Ecol 67:699-704

Virtue P, Nichols PD, Nicol S, Hosie G (1996) Reproductive trade off in male Antarctic krill, Euphausia superba. Mar Biol 126:521-527

Watanuki Y, Kato A, Sato K, Niizuma Y, Bost CA, Maho YL, Naito Y (2002) Parental mass change and food provisioning in Adélie penguins rearing chicks in colonies with contrasting sea-ice conditions. Polar Biol 25:672-681

Wilson GR, Cooper SJ, Gessaman JA (2004) The effects of temperature and artificial rain on the metabolism of American kestrels Falco sparverius. J Comp Physiol A 139: 389-394

> Wöhrmann AP, Hagen W, Kunzmann A (1997) Adaptation of the Antarctic silverfish Pleuragramma antarcticum (Pisces: Nototheniidae) to pelagic life in high-Antarctic waters. Mar Ecol Prog Ser 151:205-218 
Appendix 1. Chick growth model

The Adélie penguin Pygoscelis adeliae chick growth model was designed to represent current chick growth conditions off Anvers Island. The model focuses on processes that occur during the chick growth period at this location, which typically starts near 19 December and ends around 10 February. These dates are based on average hatch and fledge dates at Anvers Island. The governing equation for the model assumes that chick growth, expressed as the change in mass $(M, \mathrm{~kg})$ over time $(t)$, can be calculated as the difference between the energy available for production $\left(E_{\mathrm{p}}, \mathrm{kJ}\right)$ and that lost to metabolic costs $\left(E_{\mathrm{C}}, \mathrm{kJ}\right)$, scaled by the chick wet mass energy density $\left(\mathrm{ED}_{\mathrm{cwm}}, \mathrm{kJ} \mathrm{kg}^{-1}\right)$ :

$$
\frac{\mathrm{d} M}{\mathrm{~d} t}=\frac{E_{\mathrm{p}}-E_{\mathrm{c}}}{\mathrm{ED}_{\mathrm{cwm}}}
$$

The energy available for production is given by the product of the total mass of prey provisioned to the chick (Prov, $\mathrm{kg}$ ), the prey wet mass energy density (Prey ${ }_{\mathrm{wm}}, \mathrm{kJ} \mathrm{kg}^{-1}$ ) and the assimilation (digestive) efficiency (AE, 0.69 to 0.80 unitless) (Cooper 1977, Jackson 1986, Janes 1997) of the chick:

$$
E_{\mathrm{p}}=\operatorname{Prov} \cdot \text { Prey }_{\mathrm{wm}} \cdot \mathrm{AE}
$$

Prey wet mass energy density for the Antarctic krill Euphausia superba diet is estimated as described in Chapman et al. (2009) and is a function of lipid content which varies with krill sex and/or maturity stage distribution and season (Clark 1980, Virtue et al. 1996, Hagen et al. 2001). Prey wet mass for diets, including fish species, is calculated as described previously.

In the model, the amount of Antarctic krill provisioned to the chick is adequate to produce simulated growth rates, and fledging mass of either $3.09 \mathrm{~kg}$ (mean of the re-sighted and not re-sighted fledge mass [RFM and NRFM, respectively]) or $3.15 \mathrm{~kg}$ (RFM), which produces the 2 reference simulations used in the present study. The energetic costs experienced by the chick are determined by the mean field metabolic rate (FMR) and amount of energy needed to transform chick tissue into its new wet mass energy density, which increases with chick age. Mean metabolic rate, water content, chick dry mass energy density, and assimilation efficiency vary with chick age and size. Additional details of the Adélie penguin chick growth model used in the present paper are given in Chapman et al. (2009).

Appendix 2. Meteorological data

Equations used to calculate the wetting effect require daily mean values for wind speed, ambient temperature, incident solar radiation (insolation), air density, and specific humidity. Daily means of hourly values for these meteorological data during the Adélie penguin Pygoscelis adeliae nestling period between 1995 and 2004 were obtained from the British Antarctic Survey (www.antarctica.ac.uk/met/metlog). These meteorological time series were used in the simulations that explored the effect of annual variability in weather conditions on chick fledging mass.

Meteorological data were representative of conditions at colonies off Anvers Island. With the exception of insolation, data are from the Vernadsky (Ukraine) station, which is $55 \mathrm{~km}$ south of Anvers Island (prior to 1996, this was Faraday Station operated by the British Antarctic Survey). Insolation data are from Rothera Station, which is $360 \mathrm{~km}$ southwest of Anvers Island. This was the closest location where insolation data were available between 1995 and 2004. Mean daily insolation data from Rothera Station between 1995 and 2004 from the chick-rearing period were only slightly higher than those measured by Chappell et al. (1990) at Torgerson Island (just off Anvers Island) during 1986 (204 W m ${ }^{-2}$ compared to $191 \mathrm{~W} \mathrm{~m}^{-2}$ ). Given the limited contribution that insolation makes to the calculation of the operative temperature, the data from Rothera were considered appropriate for use in the present study. Wind speed was measured at $10 \mathrm{~m}$, though the winds experienced by chicks are at heights of $<0.5 \mathrm{~m}$. Therefore, measured winds were attenuated based on an analysis of concurrent data sets collected at $10 \mathrm{~m}$ and at $0.35 \mathrm{~m}$ (the height of a large chick). Wind speeds measured at Faraday/Vernadsky Station in 1986 were compared with concurrent wind speeds measured at $0.35 \mathrm{~m}$ during the 1986 breeding season near Palmer Station off Anvers Island (Chappell et al. 1990). Wind data were modified by a factor of 0.67 in order to adjust for differences in wind speeds measured at Faraday/Vernadsky and those measured at chick height near Palmer Station. With this adjustment, the mean wind measurement from both data sets (Palmer Station data reported in Chappell et al. [1990] and the modified wind data from Faraday/Vernardsky from the same time period) were the same $\left(2.6 \mathrm{~m} \mathrm{~s}^{-1}\right)$, and the proportion of measurements $>1 \mathrm{~m} \mathrm{~s}^{-1}$ (just over 0.80 reported in Chappell et al. [1990] compared to 0.83 from Faraday/Vernadsky) were essentially equivalent.
Editorial responsibility: Rory Wilson, Swansea, UK
Submitted: October 13, 2009; Accepted: June 6, 2011 Proofs received from author(s): August 24, 2011 